\title{
Impact on Patient Satisfaction and Importance of Medical Intake and Office Staff in a Multidisciplinary, One-Stop Shop Transgender Program in Indianapolis, Indiana [Corrigendum]
}

\author{
Nowaskie DZ, Fogel RS, Fogel JM. J Multidiscip Healthc. \\ 2019;12:665-673.
}

On page 672, Credentials section, "Janine Fogel, MD: Janine is a family medicine physician at Eskenazi Health. She is the founder of the first and only transgender program in Indiana." should read "Janine Fogel, MD: Janine is a family medicine physician at Eskenazi Health. She is the founder of the first transgender program in Indiana."

Following feedback from a provider in northern Indiana, who had started a transgender program not too long after ours, the wording has been updated so that we are not misrepresenting other work being done.

\section{Publish your work in this journal}

The Journal of Multidisciplinary Healthcare is an international, peerreviewed open-access journal that aims to represent and publish research in healthcare areas delivered by practitioners of different disciplines. This includes studies and reviews conducted by multidisciplinary teams as well as research which evaluates the results or conduct of such teams or healthcare processes in general. The journal covers a very wide range of areas and welcomes submissions from practitioners at all levels, from all over the world. The manuscript management system is completely online and includes a very quick and fair peer-review system. Visit http://www.dovepress.com/testimonials. php to read real quotes from published authors. 